\title{
Ampulla of Vater Enterochromaffin Cell Serotonin-Producing Neuroendocrine Tumor
}

National Cancer Institute

\section{Source}

National Cancer Institute. Ampulla of Vater Enterochromaffin Cell Serotonin-Producing Neuroendocrine Tumor. NCI Thesaurus. Code C95987.

A well differentiated neuroendocrine tumor that arises from the ampulla of Vater and the periampullary region. It produces serotonin. 